\title{
Peningkatan Kemampuan Membaca Permulaan Anak Cerebral Palsy melalui Pemahaman Notasi Alfabet pada Permainan Djembe di SLB-D
}

\author{
Abdul Matiin Haqq ${ }^{1}$, Genesa Vernanda ${ }^{2}$ \\ ${ }^{12}$ Universitas Muhammadiyah Lampung, Indonesia \\ Email:abdul.matiin.haqq@gmail.com
}

\begin{tabular}{l} 
INFORMASI ARTIKEL \\
\hline Terkirim 30 Agustus 2018 \\
Revisi 08 Oktober 2018 \\
Diterima 19 November 2018 \\
\hline Katakunci: \\
Siswa Cerebral Palsy, Kemampuan \\
Membaca Permulaan, Pemahaman \\
Notasi Alfabet Pada Permainan \\
Djembe.
\end{tabular}

\section{INFORMASI ARTIKEL}

irim 30 Agustus 20

\begin{abstract}
ABSTRAK
Penelitian ini dilakukan di SLB-D, dengan Subjek tunggal yang berinisial IL kelas 3 SMA. Minat dan motavasi IL dalam pembelajaran membaca sangat kurang yang berdampak pada kemampuan membaca permulaanya. Hal itu melatarbelakangi peneliti melakukan penelitian ini yang bertujuan untuk mengetahui sejauh mana pengaruh pemahaman notasi alfabet pada permainan djembe terhadap kemampuan membaca permulaan siswa cerebral palsy. Peningkatan kemampuan membaca permulaan dapat terlihat dari hasil data pada fase Baseline-1, Intervensi, dan Baseline-2. Kemampuan dalam membaca permulaan meliputi; mengenal huruf, membaca suku kata, membaca kata dan membaca kalimat sederhana. Metode yang digunakan adalah metode eksperimen dengan menggunakan pendekatan Single Subject Research dengan menggunakan desain A-B-A. Penyajian data diolah dan dianalisis menggunakan statistik deskriptif dengan persentase dan ditampilkan dalam bentuk grafik. Hasil penelitian ini menunjukan bahwa mean kemampuan awal IL dalam dalam membaca permulaanpada fase Baseline-1 dengan mean sebesar 30,07\% yang menggambarkan kemampuan membaca permulaan masih kurang, setelah melewati fase intervensi kemampuan membaca permulaan meningkat dengan mean sebesar $79 \%$ pada fase Baseline-2 yang artinya baik. Berdasarkan temuan hasil penelitian ini, membuktikan bahwa pembelajaran melalui pemahaman notasi alfabet pada permainan djembe berpengaruh pada peningkatan kemampuan membaca permulaan IL, siswa cerebral palsy di SLB-D.
\end{abstract}

This is an open access article distributed under the Creative Commons 4.0 Attribution License, This license lets others remix, tweak, and build upon your work even for commercial purposes, as long as they credit you and license their new creations under the identical terms $\odot 2018$ by author and Universitas Negeri Padang.

\section{Pendahuluan}

Berdasarkan hasil studi pendahuluan yang dilakukan penulis kepada peserta didik cerebral palsy spastic dengan hambatan kognitif, proses pencarian informasi dilaksanakan pada proses pembelajaran Bahasa Indonesia dengan materi ajar berupa pemahaman teks bacaan. Dalam proses pembelajaran peserta didik diberikan penugasan untuk membacakan teks cerita dan menceritakan kembali isi cerita yang terdapat dalam teks bacaan tersebut. Pada proses membaca, peserta didik mengalami kekeliruan membaca beberapa kata pada setiap kalimat yang mengakibatkan peserta didik sulit memahami teks bacaan tersebut. Selain itu, penulis mendapatkan informasi dari orang tua peserta didik mengenai perkembangan kemampuan membaca peserta didik yang penulis teliti yang berinisial IL. Menurut orang tua IL, dari usia sekolah dasar hingga SMP minat belajar membaca IL sangat rendah, namun saat IL duduk di kelas 3 SMP minat membaca IL meningkat dikarenakan adanya guru baru yang disenangi IL. Selama IL diajar oleh guru tersebut, minat dan kemampuan membacanya meningkat, namun ketika guru tersebut sudah tidak mengajar IL di tempat IL bersekolah minat dan kemampuan membaca IL kembali menurun.

Berdasarkan latar belakang tersebut peneliti tertarik untuk meneliti dan meningkatkan kemampuan membaca permulaan IL, dengan menggunakan pendekatan kegiatan yang disenangi IL yaitu permainan alat musik djembe yang telah dimodifikasi dengan menggunakan notasi musik

Suatu pembelajaran bahasa tidaklah terlepas dari aspek membaca, pada dasarnya proses pembelajaran bahasa diawali oleh proses membaca dan dilanjutkan pada proses pemahaman isi bacaan tersebut. Menurut Abdurrahman (2012:158) “... membaca merupakan aktivitas kompleks yang mencakup fisik dan mental. Aktivitas fisik yang terkait dengan membaca adalah gerak mata dan ketajaman penglihatan. Aktivitas mental mencakup ingatan dan pemahaman". Anak dengan hambatan kognitif mengalami hambatan dalam ingatan dan pemahaman dalam proses membaca. Hal ini terjadi pada subjek penelitian yang penulis teliti. Menurut Bond dalam Abdurrahman (2012:158) "membaca merupakan pengenalan simbol-simbol bahasa tulis yang merupakan stimulus yang membantu proses mengingat tentang apa yang dibaca, untuk membangun suatu pengertian melalui pengalaman yang telah dimiliki”. Berdasarkan kutipan di atas, melalui membaca kita dapat memperoleh informasi dari isi bacaan yang kita baca. Manfaat yang diperoleh dari informasi yang kita baca adalah bertambahnya wawasan dan meningkatnya kemampuan komunikasi, khususnya komunikasi non-verbal.

Pemerolehan informasi dari teks bacaan termasuk dalam keterampilan membaca lanjut/pemahaman. Sebelum mencapai tahapan membaca lanjut/pemahaman diperlukan keterampilan membaca per-simbol tertulis berupa huruf atau kata menjadi system bunyi.

Menurut Hardman (Wardhani, et al., 2007) '45\% anak cerebral palsy mengalami keterbelakangan mental (tunagrahita), 35\% mempunyai tingkat kecerdasan normal dan diatas normal. Sisanya berkecerdasan sedikit di bawah rata-rata'. Selain gangguan kecerdasan anak cerebral palsy juga mengalami kelainan persepsi, kognisi dan simbolisasi. Kelainan persepsi disebabkan karena rusaknya jaringan saraf dan saraf penghubung ke otak sehingga penafsiran dan analisis stimulus pun mengalami gangguan. Hambatan kognisi juga bisa terjadi pada anak cerebral palsy karena kerusakan pada otak sehingga mengganggu fungsi kecerdasan, penglihatan, pendengaran, bicara dan bahasa. Gangguan simbolisasi dikarenakan adanya kesulitan dalam menerjemahkan apa yang didengar dan dilihat. Hambatan yang kompleks ini akan mempengaruhi prestasi akademiknya. Hambatan-hambatan saraf ini pula yang mempengaruhi kemampuan membaca anak cerebral palsy karena dalam membaca diperlukan kemampuan persepsi, kognisi dan simbolisasi (Wardhani, et al., 2007).

"Anak tunadaksa adalah anak yang mengalami kelainan atau kecacatan pada system otot, tulang dan persendian yang mungkin disebabkan oleh adanya penyakit atau kecelakaan dan juga karena congenital, dan atau kerusakan otak yang dapat mengakibatkan gangguan gerak, kecerdasan, komunikasi, persepsi, kordinasi, perilaku dan adaptasi" (Widati, $2007: 1$ ). 
Salah satu jenis anak tunadaksa adalah anak cerebral palsy. "Cerebral palsy adalah suatu kelainan gerak, postur, atau bentuk tubuh, gangguan kordinasi, dan kadang disertai dengan gangguan psikologis dan sensori yang disebabkan oleh adanya kerusakan pada masa perkembangan otak." (Widati, $2007: 2)$.

Terdapat beberapa macam jenis cerebral palsy, salah satunya adalah cerebral palsy spastic. Anak cerebral palsy spastic mengalami gangguan fungsi motorik (kekakuan, kelumpuhan, kurangnya kordinasi gerak, hilang keseimbangan, munculnya gerakan-gerakan ritmis, dan atau terdapat kekejangan pada otot) dan pada jenis cerebral palsy spastic ini mengalami kerusakan pada organ bicaranya yang mengakibatkan sulit dalam pengucapan bunyi yang terkadang menjadikan anak menjadi malas dalam membaca dan minat membaca menjadi kurang.

"Notasi adalah tulisan musik; lambang tulisan musik" (Kamus Musik, 2003:299). Notasi musik ini penulis modifikasi menjadi notasi alfabet yang nantinya notasi huruf ini tersusun dalam beberapa bar dengan pola huruf yang ditentukan oleh penulis, contohnya: $|\mathrm{r}-\mathrm{a}-\mathrm{g}-\mathrm{i}-1| \mathrm{m}-\mathrm{e}-\mathrm{m}-\mathrm{b}-\mathrm{a}$ $-\mathrm{c}-\mathrm{a} \mid \mathrm{k}-\mathrm{o}-\mathrm{r}-\mathrm{a}-\mathrm{n} \quad$ Pada akhirnya IL akan dilatih membaca kata-kata yang tersusun dalam beberapa bar (kata) tersebut berulang-ulang setelah IL memainkan alat musik djembe dengan pola tersebut.

Djembe merupakan alat musik perkusi yang berasal dari Afrika barat, memukul alat musik ini menggunakan tangan kosong. Alat musik djembe sudah tidak asing lagi dipakai untuk mengiringi sebuah lagu dan juga sering pakai dalam pementasan perkusi. Dan alat musik ini sudah sangat mudah didapatkan di tempat-tempat yang menjual alat musik.

Dalam permainan alat musik djembe ini umumnya dapat meningkatkan kemampuan motorik kasar maupun halus fakta ini diperkuat oleh penelitian yang dilakukan penelitan sebelumnya. Dan juga dapat meningkatkan aspek-aspek lain seperti atensi, konsentrasi dan motivasi itu semua bagaimana mengemas permainan dari alat musik djembe itu sendiri. Dalam penelitian ini penulis mencoba menggunakan alat musik djembe sebagai media peningkatan kemampuan membaca.

Dengan melakukan kegiatan yang disenangi oleh anak sebelum pembelajaran dan pada saat pembelajaran diharapkan minat peserta didik untuk belajar membaca meningkat sehingga memudahkan peserta didik untuk belajar membaca permulaan dengan kondisi pembelajaran yang menyenangkan. Melalui penelitian ini diharapkan menjadi salah satu solusi dari permasalahan yang dialami oleh subjek peneliti dalam aspek menyimak dalam proses pembelajaran bahasa.

\section{Metode}

\subsection{Metode Penelitian}

Pola desain tunggal yang dipakai adalah pola A-B-A, yang terdiri dari tahapan kondisi A1 (baseline 1), B (perlakuan), A2 (baseline 2). Dalam penelitian ini A1 yakni kemampuan dasar, yaitu kemampuan membaca permulaan siswa saat proses belajar mengajar berlangsung. Hal ini bisa diukur dari:

2.1.1. Kemampuan membaca suatu kata masih sering keliru.

2.1.2. Kemampuan membaca suatu kalimat masih sering keliru.

Pengamatan dan pengambilan data tersebut dilakukan secara berulang untuk memastikan data yang sudah didapat dan melihat kemampuan awal anak secara pasti, serta dilaksanakan dalam suasana alami, yakni tidak dibuat-buat, dan tidak diketahui anak, bahwa anak sedang diobservasi.

B (perlakuan atau intervensi) yang diberikan berupa penerapan permainan djembe sebelum dan saat proses pembelajaran berlangsung. Serta dilihat kemampuan membaca permulaan pada pelajaran Bahasa Indonesia.

A2, yakni pengamatan kembali terhadap kemampuan membaca permulaan anak tunadaksa yang menjadi subjek penelitian. Hal ini juga dapat menjadi evaluasi sejauh mana intervensi yang diberikan berpengaruh terhadap subjek.Secara visual desain A-B-Adapat digambarkan pada grafik di bawah ini:

Gambar. 1. A-B-A

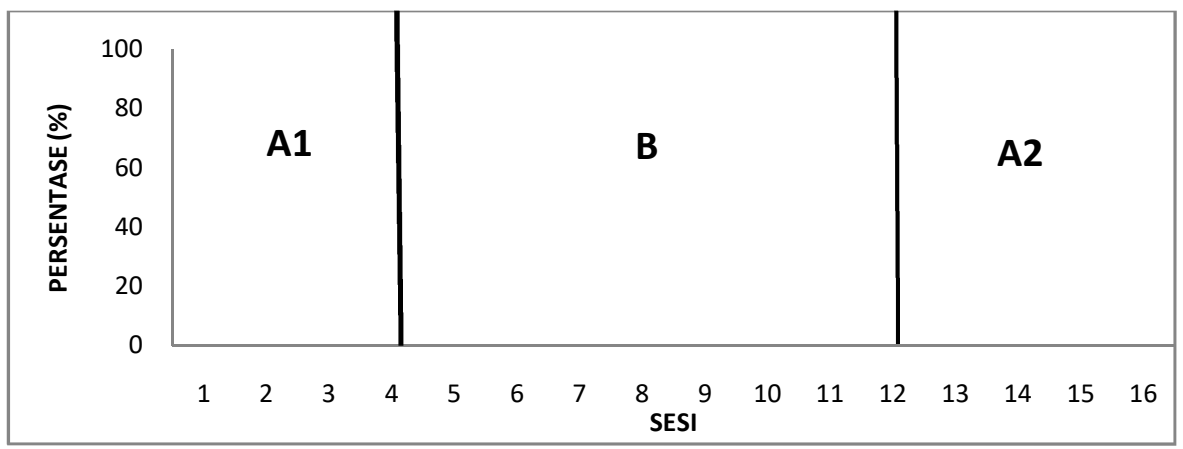

\subsection{Variabel Penelitian}

Menurut Sunanto, Takeuchi dan Nakata (2005:12) "Variabel merupakan suatu atribut atau ciri-ciri mengenai sesuatu diamati dalam penelitian

Dengan demikian variabel dapat berbentuk benda atau kejadian yang dapat diamati dan diukur" .pada penelitian ini terdapat dua variabel yaitu:

\section{Variabel Bebas}

Variabel bebas adalah variabel yang mempengaruhi atau yang menjadi sebab timbulnya variabel terikat. Variabel bebas dalam penelitian ini adalah notasi huruf alfabet dalam permainan djembe.

Dalam Kamus Musik (2003:299), secara bahasa "notasi adalah tulisan musik; lambang tulisan musik", sedangkan menurut Badudu (2003: 244) "notasi itu memiliki beberapa arti yaitu sistem lambang (nada) yang menggambarkan bilangan, nada atau ujaran dan proses perlambangan bilangan nada ujaran dengan lambang". Notasi dalam musik ini bertujuan untuk mempermudah memainkan musik yang biasanya tertuangan dalam sebuah partitur.

Notasi musik merupakan lambang-lambang musik yang tertulis. Menurut Tim Seni Musik SMA (2002), notasi musik ada 3 yaitu notasi angka, notasi huruf dan notasi balok 
Dalam skripsi T.P.Sari (2012: 18-19),"Notasi huruf merupakan notasi paling mudah yang didasarkan pada bunyi nadanya. Membaca notasi melodi dengan do re mi fa sol la si do. Notasi ini dikemukakan oleh John Curwen (1816 - 1880) seorang tokoh perkumpulan gereja Indonesia. Contoh notasi sebagai berikut I: D ; m. m I r : . r I d : -II akan tetapi disederhanakan sesuai keperluan. Not yang berdiri sendiri yaitu d r m f s 1 t. $\operatorname{tanda}$ panjang lanjutan not disimbolkan dengan - (d-). Sedangkan tanda diam disimbolkan dengan o".

Tabel. 1. Notasi Huruf

\begin{tabular}{lccccccccc}
\hline Simbol angka & $\mathbf{1}$ & $\mathbf{2}$ & $\mathbf{3}$ & $\mathbf{4}$ & $\mathbf{5}$ & $\mathbf{6}$ & $\mathbf{7}$ & $\mathbf{1}$ \\
\hline Solmisasi & do & re & mi & fa & sol & la & si(ti) & do \\
\hline Not huruf & d & r & m & f & s & l & t & 'd \\
\hline
\end{tabular}

Djembe merupakan alat musik perkusi yang berasal dari Afrika barat, memukul alat musik ini menggunakan tangan kosong. Alat musik djembe sudah tidak asing lagi dipakai untuk mengiringi sebuah lagu dan juga sering pakai dalam pementasan perkusi. Permainan djembe ini sangat digemari oleh banyak orang, salah satunya subjek peneliti sendiri.

Notasi huruf yang digunakan pada biasanya digunakan pada alat musik melodi yang menghasilkan nada-nada diatonis/pentatonis. Pada kutipan diatas juga terdapat penyederhanaan simbol notasi huruf yang awalnya rumit untuk diterjemahkan menjadi notasi yang mudah untuk diterjemahkan. Penulis menginovasi penggunaan notasi huruf ini, yang awalnya dipakai untuk alat musik melodi, penulis mencoba untuk dipakai dalam permainan alat musik ritmis, salah satunya alat musik djembe yang nantinya dipakai dalam proses pembelajaran membaca permulaan. Terdapat modifikasi dalam penyimbolan notasi huruf ini, yang awalnya notasi huruf ini terdiri dari 7 huruf untuk mewakili dari setiap nada diatonic menjadi 26 huruf yang terbagi menjadi 2 kelompok yaitu huruf konsonan yang nantinya akan menjadi simbol untuk memukul djembe dan huruf vocal sebagai simbol tidak boleh memukul djembe. Notasi huruf yang penulis modifikasi ini diberinama notasi alfabet yang bertujuan untuk membantu anak dalam belajar membaca permulaan dan juga menciptakan proses belajar yang menyenangkan. Notasi alfabet ini tersusun dalam sebuah partitur yang terdiri dari beberapa bar, dan 1 bar ini mewakili dari satu kata dan pada akhirnya kata-kata ini tersusun menjadi sebuah kalimat, contohnya: $|\mathrm{r}-\mathrm{a}-\mathrm{g}-\mathrm{i}-\mathrm{l}| \mathrm{m}-\mathrm{e}-\mathrm{m}-\mathrm{b}-\mathrm{a}-\mathrm{c}-\mathrm{a} \mid \mathrm{k}-\mathrm{o}-\mathrm{r}-\mathrm{a}$ - n |, dalam notasi alphabet terdapat 2 kelompok, yaitu: lambang huruf menjadi simbol memukul djembe (aksen bunyi) dan lambang “-“ menjadi simbol tidak memukul djembe. Dalam proses pembelajaran membaca dalam permainan djembe ini mengadopsi metode membaca alfabetik yang nantinya siswa akan membaca dari huruf, suku kata, kata sampai dengan kalimat. Langkah-langkah dalam pembelajaran:

3.1.1. Menjelaskan materi yang akan diajarkan kepada siswa, tujuan, manfaat dari pembelajran membaca.

3.1.2. Melakukan pemanasan dengan memukul djembe dengan tempo lambat sebelum pembelajaran membaca dimulai.

3.1.3. Menjelaskan cara membaca notasi alfabet dan aturan cara bermain djembe dengan membaca notasi alfabet.

3.1.4. Membaca notasi alfabet yang menjadi materi pelajaran membaca.

3.1.5. Di tengah proses pembelajaran, siswa diberikan permainan djembe yang lebih atraktif untuk menaikan minat siswa dalam proses membaca notasi alfabet pada permainan djembe.

\section{Variabel Terikat}

Variabel terikat adalah variabel yang dipengaruhi atau yang menjadi akibat, karena adanya variabel bebas. Variabel terikat atau target behavior yang ingin dicapai dalam penelitian ini, yaitu kemampuan membaca permulaan anak cerebral palsy di SLB D.

Membaca merupakan salah satu keterampilan dasar untuk mencapai tujuan pembelajaran akademik di sekolah. Menurut Bond dalam Abdurrahman (2012:158) "membaca merupakan pengenalan simbol-simbol bahasa tulis yang merupakan stimulus yang membantu proses mengingat tentang apa yang dibaca, untuk membangun suatu pengertian melalui pengalaman yang telah dimiliki". Dalam kutipan di atas bahwa pada proses membaca, seorang pembaca akan mendapat sebuah informasi dari bacaan yang dibacanya. Menurut Purwanto dan Alim (1997: 29) "Membaca permulaan mengutamakan pengajaran huruf dan rangkaiannya, serta melancarkan teknik membaca".

Untuk mengetahui peningkatan subjek dalam membaca permulaan, yang meliputi (1) Mengenal huruf, (2) Membaca suku kata, (3) Membaca kata, (4) Membaca kalimat, dapat diukur dengan menggunakan tes perbuatan, yaitu dengan memberikan instruksi kepada siswa untuk membaca huruf, suku kata, kata dan kalimat. Adapun tahap pemberian tes adalah:

3.2.1. Sebelum siswa diberikan intervensi membaca notasi alfabet dalam permainan djembe, yang berfungsi untuk melihat kemampuan awal siswa mengenai kemampuan membaca permulaannya.

3.2.2. Saat diberikan intervensi, berfungsi untuk melihat pencapaian kemampuan membaca permulaan siswa selama proses membaca alfabet dalam permainan djembe.

3.2.3. Setelah diberikan intervensi, yang berfungsi untuk melihat hasil akhir setelah melaksanakan latihan membaca notasi huruf alfabet dalam permainan djembe.

\subsection{Instrumen Penelitian}

Dalam suatu penelitian terdapat proses pengukuran dan dalam proses pengukuran tersebut harus memiliki alat ukur, dan instrument penelitian menjadi alat ukur dalam suatu penelitian.

“instrumen penelitian adalah suatu alat yang digunakan mengukur fenomena alam maupun sosial yang diamati”(Sugiyono, 2008:102). Fenomena yang dimaksud adalah variable penelitian. Instrmen peneletian merupakan bagian penting untuk mendapatkan data-data yang diperlukan dalam penelitian dan instrumen yang digunakan dalam penelitian adalah tes lisan. Tes lisan ini untuk mengukur ada atau tidaknya kemampuan objek yang diteliti (Arikunto, 1997). Tes dalam penelitian ini dilakukan pada setiap sesi. Satu sesi ini terhitung sebagai satu kali pertemuan. Tes lisan diberikan kepada 
peserta didik padafase baseline 1 (A-1) untuk mengetahui kemampuan membaca permulaan sebelum diberikan intervensi. Tes lisan diberikan pada fase intervensi (B) untuk mengetahui kemampuan peserta didik selama diberi perlakuan atau intervensi, dan tes lisan pada fase baseline 2 (A-2) yang bertujuan untuk melihat apakah setelah pemberian intervensi atau perlakuan telah memberikan pengaruh terhadap kemampuan membaca permulaan terhadap peserta didik yang diteliti.

Adapun skoring yang dilakukan setiap pelaksanaan tes lisan yang bertujuan untuk menghitung persentase peningkatan kemampuan membaca permulaan dan dapat dihitung sebagai berikut:

Persentase $=($ jumlah soal yang dijawab)/(jumlah seluruh soal) $x 100 \%$

\section{Hasil Penelitian dan Pembahasan}

Kegiatan yang disenangi oleh anak dalam proses pembelajaran dapat meningkatkan motivasi dan minat anak. Pada kegiatan tersebut dapat menciptakan suasana yang menyenangkan dan materi pembelajaran mudah ditangkap oleh siswa. Salah satu intervensi yang dilakukan peneliti adalah gabungan dari kegiatan yang disenangi oleh anak yaitu bermain alat musik djembe dan metode membaca permulaan yaitu metode alfabetik. Kegiatan yang disenangi oleh anak ini yatu bermain djembe penulis ketahui berdasarkan pengalaman praktek di SLB- D. Subjek sangat antusias sekali terhadap kegiatan ekskul perkusi terutama bermain djembe, bahkan ketika tidak ada jadwal ekskul tersebut pun, subjek sering meminta praktikan untuk mengajarkan dan bermain djembe bersama. Terlihat pada saat bermain djembe subjek terlihat menikmati permainan tersebut. Permain djembe ini mudah dilakukan oleh orang yang baru belajar bermain alat musik karena cara bermain alat musik djembe lebih sederhana dibandingkan dengan alat musik lainnya. Melihat minat anak kurang dalam belajar membaca, dan anak menyukai kegiatan bermain djembe, penulis menggabungkan dua kegiatan tersebut menjadi satu yaitu belajar membaca permulaan melalui pemahaman notasi alfabet pada permainan djembe yang menjadikan salah satu bentuk intervensi pada penelitian ini, pada pelaksanaannya anak belajar membaca sambil bermain.

Hasil penelitian berdasarkan analisis dalam kondisi meliputi baseline-1 (A1), intervensi (B), dan baseline-2 (A2). Pada fase baseline-1 ini didapat tiga data yang stabil dengan mean 30,07\%, setelah mengetahui data pada fase baseline-1 stabil peneliti memulai fase intervensi. Pada fase intervensi menghasilkan data yang stabil setelah diberikan intervensi sebanyak delapan sesi dengan mean $81,42 \%$. Pada komponen kecenderungan stabilitas pada fase intervensi, subyek mendapatkan perubahan data $4,31 \%$ yang menunjukan subyek mengalami peningkatan kemampuan membaca permulaan. Pada fase intervensi terlihat minat anak lebih muncul dalam pelaksanaan pembelajaran dan yang berdampak langsung pada kemampuan membaca pada fase intervensi lebih meningkat dari kemampuan awal pada fase baseline-1, berbeda dengan pada fase baseline-1, anak terlihat kurang bersemangat untuk membaca walaupun hanya beberapa kalimat sederhana dan setelah melakukan intervensi sebanyak 8 sesi dan data menunjukan telah stabil, kemudian dilanjutkan pada fase baseline-2. Hasil analisis dalam kondisi pada baseline-2, didapat data stabil setelah melakukan 3 sesi pengambilan data dan fase ini diakhiri dengan mean $79 \%$.

Gambar. 2. Presentase Hasil Data Keseluruhan Kemampuan Membaca Permulaan

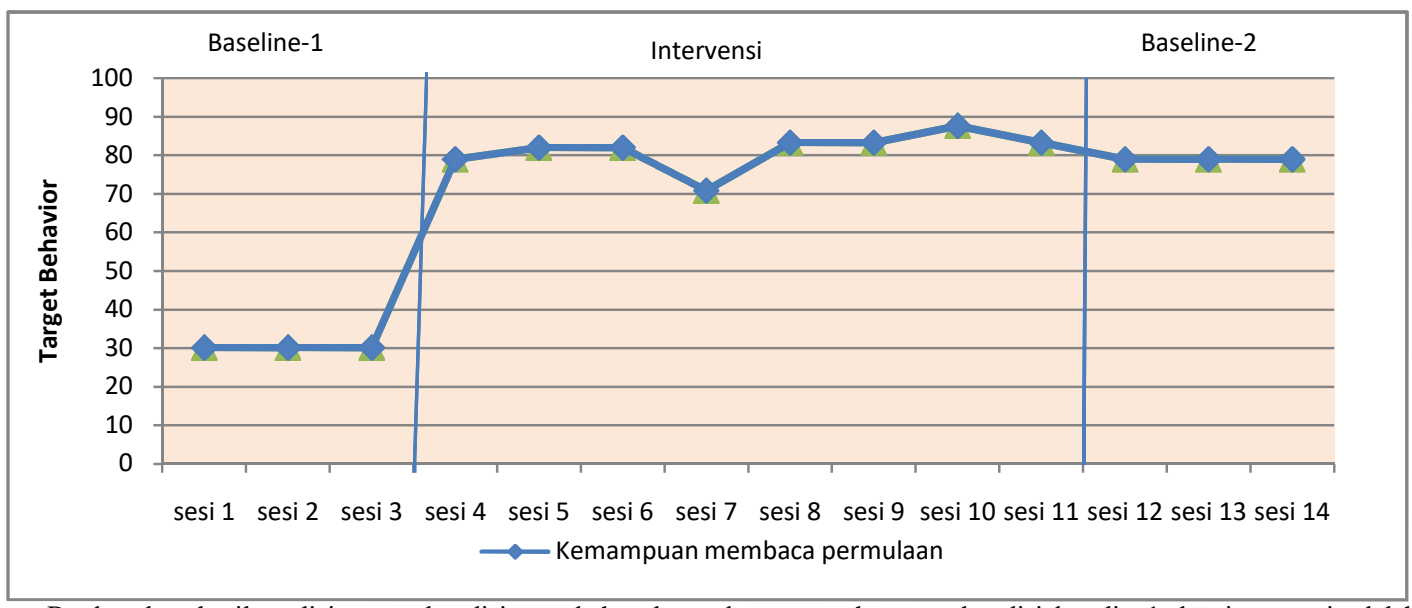

Berdasarkan hasil analisis antar kondisi, perubahan kecendrungan arah antara kondisi baseline1 dan intervensi adalah mendatar ke menaik dan mengalami perubahan level sebesar (+) 48,91\%. Hal ini menggambarkan adanya peningkatan kemampuan membaca permulaan yang disebabkan oleh intervensi berupa pemahaman notasi alfabet pada permainan djembe. Tidak terdapatnya data yang tumpang tindih antara baseline-1 (A1) dengan intervensi (B), yang menunjukan adanya peningkatan membaca permulaan anak cerebral palsy melalui pemahaman notasi alfabet pada permainan djembe.

\section{Kesimpulan}

Berdasarkan hasil dari pengolahan data penelitian yang telah dijelaskan pada bagian pembahasan dan dapat diketahui bahwa kemampuan membaca permulaan IL yang meliputi beberapa aspek seperti, mengenal huruf, membaca suku kata, membaca kata, dan membaca kalimat pada fase baseline-1 sangat kurang. Hasil dari analisis data terdapat peningkatan kemampuan membaca permulaan pada fase intervensi yang diberikan perlakuan melalui pemahaman notasi alfabet pada permainan djembe yang meliputi kemampuan membaca huruf, suku kata, kata dan kalimat sederhana. Pada baseline-1 memiliki mean level sebesar 30,07\%, pada fase intervensi kemampuan membaca permulaan mengalami peningkatan dengan mean level sebesar81,42\% 
dan pada baseline-2, fase setelah diberikan intervensi memilik mean level sebesar 79\%. Dari perbandiangan kemampuan membaca permulaan sebelum diberikan intervensi (baseline-1) dengan kemampuan membaca permulaan setelah diberikan intervensi (baseline-2) dapat disimpulkan terdapat peningkatan kemampuan membaca permulaan anak cerebral palsy melalui pemahaman notasi alfabet pada permainan djembe di SLB D.

\section{Daftar Rujukan}

Abdurrahman, M. (2012). Anak berkesulitan belajar: teori, diagnosis, dan remediasinya. Jakarta: Rineka Cipta.

Arikunto, S. (2006). Prosedur Penelitian Suatu Pendekatan Praktik. Jakarta: PT Rineka Cipta.

Badudu, Y. (2003). Kamus kata-kata serapan asing dalam bahasa Indonesia. Penerbit Buku Kompas.

Banoe, P. (2003). Kamus musik. Kanisius.

Delphie, B. (2006). Pembelajaran anak berkebutuhan khusus. Bandung: Refika Aditama.

Lubis, Ibrahim. (2012). Hakikat Pembelajaran Efektif. Diakses dari: http://makalahmajannaii.blogspot.com/2012/02/hakikatpembelajaran-efektif.html.

Sugiarmin, M., \& Muslim, A. T. (1995). Ortopedi Dalam Pendidikan Anak Tuna Daksa.. DEPDIKBUD.

Natawidjaja, R. (1979). Pengantar Pendidikan Luar Biasa. Jakarta: Depdikbud.

Purwanto, M. N., Alim, D., \& Falah, N. (1997). Metodologi pengajaran bahasa Indonesia: di sekolah dasar. PT Rosda Jayaputra.

Rochyadi, Endang. (2011). Model Pembelajaran Berbasis Kesadaran Linguistik dan Kesadaran Persepsi Visual Untuk Meningkatkan Kemampuan Anak Tunagrahita, Program Doktoral Pendidikan Khusus, Universitas Pendidikan Indonesia, Bandung.

Sari, T. P. (2012). Pengembangan Software Notasi Angka.

Seno, T. (2008). Djembe dari Bali. Diakses dari: http://tonyseno.blogspot.com/2008/01/djembe-dari-bali.html.

Sugiarsih, S. (2010). Permainan Bahasa dalam Pembelajaran Bahasa Indonesia di Sekolah Dasar. Yogyakarta: Universitas Negeri Yogyakarta.

Sugiyono. (2008). Metode penelitian pendidikan:(pendekatan kuantitatif, kualitatif dan $R \& D$ ). Alfabeta.

Sunanto, J., Takeuchi, K., \& Nakata, H. (2006). Penelitian dengan subjek tunggal. Bandung: UPI Pres.

Tarigan, H.G. (2008). Membaca sebagai suatu keterampilan berbahasa. Bandung:PT Angkasa.

Tim Seni Musik SMA. (2002). Pendidikan Seni Musik 1 untuk SMA Kelas 1. Bekasi: PT Galaxy Puspa Mega.

Wardani, I.G.A.K. ,Hernawati, T. , Astati. (2007). Pengantar Pendidikan Luar Biasa. Jakarta: Universitas Terbuka.

Widati, S. (2007). Pendidikan Anak Tunadaksa. Handout dalam perkuliahan PLB FIP UPI, Bandung. 